Article

\title{
Fumigation Activity against Phosphine-Resistant Tribolium castaneum (Coleoptera: Tenebrionidae) Using Carbonyl Sulfide
}

\author{
Han Kyung Lee ${ }^{1,+}{ }^{\oplus}$, Geunho Jeong ${ }^{1,+}$, Hyun Kyung Kim ${ }^{1}$, Bong-Su Kim ${ }^{2}$, Jeong-Oh Yang ${ }^{2}{ }^{\circledR}$, \\ Hyun-Na Koo ${ }^{1}$ and Gil-Hah Kim ${ }^{1, *}$ \\ 1 Department of Plant Medicine, College of Agriculture, Life and Environment Science, \\ Chungbuk National University, Cheongju 28644, Korea; dhthrms1@naver.com (H.K.L.); \\ hoo043@naver.com (G.J.); nshk0917@gmail.com (H.K.K.); hyunnakoo@hanmail.net (H.-N.K.) \\ 2 Plant Quarantine Technology Center, Animal and Plant Quarantine Agency, \\ Gyeongsangbuk-do 39660, Korea; bskim79@korea.kr (B.-S.K.); joyang12@korea.kr (J.-O.Y.) \\ * Correspondence: khkim@chungbuk.ac.kr; Tel.: +82-43-261-2555 \\ + Co-first authors.
}

Received: 28 September 2020; Accepted: 29 October 2020; Published: 31 October 2020

Simple Summary: Phosphine is one of the most widely used fumigants for the control of stored grain pests in quarantine. However, $\mathrm{PH}_{3}$ resistance to many stored pests has been reported. In this study, the fumigation activity of carbonyl sulfide was researched as an alternative fumigant to control $\mathrm{PH}_{3}$-resistant pests. In $\mathrm{PH}_{3}$ treatment, there was a clear difference in the fumigation activity of domestic strain Tribolium castaneum and resistance strain T. castaneum, but both the $\mathrm{d}$ - and $\mathrm{r}$-strains of T. castaneum showed similar results in the carbonyl sulfide (COS) treatment. Furthermore, both $\mathrm{PH}_{3}$ and COS showed no significant difference in fumigation activity in Oryzaephilus surinamensis.

Abstract: Phosphine resistance is occurring among stored-grain pests worldwide. This study investigated the fumigation activity of phosphine $\left(\mathrm{PH}_{3}\right)$ and carbonyl sulfide $(\mathrm{COS})$ against domestic strain (d-strain) Tribolium castaneum, resistance strain ( $\mathrm{r}$-strain) T. castaneum and Oryzaephilus surinamensis. All developmental stages of the pests were exposed to two fumigants $\left(\mathrm{PH}_{3}\right.$ and $\left.\mathrm{COS}\right)$, and the fumigation activity according to the dose and exposure time was evaluated in a 12-L desiccator and $0.5 \mathrm{~m}^{3}$ fumigation chamber. The rice sorption rate and quality following exposure to thetwofumigants were evaluated. The mortality was $2.9 \%$ in $\mathrm{r}$-strain $T$. castaneum, $49.5 \%$ in d-strain T. castaneum and $99.2 \%$ in O. surinamensis when $2 \mathrm{mg} / \mathrm{L} \mathrm{PH}_{3}$ was used in a $12-\mathrm{L}$ desiccator for $4 \mathrm{~h}$. However, all pest developmental stages showed $100 \%$ mortality after $24 \mathrm{~h}$ of exposure in the $0.5 \mathrm{~m}^{3}$ fumigation chamber, except for the r-strain T. castaneum. A mortalityof $100 \%$ was observed in all of the r-strain T. castaneum developmental stages at an exposure time of $192 \mathrm{~h}$. For COS applied at $40.23 \mathrm{mg} / \mathrm{L}$ and $50 \mathrm{~g} / \mathrm{m}^{3}$ in the 12-L desiccator and the $0.5 \mathrm{~m}^{3}$ fumigation chamber, respectively, $100 \%$ mortality was observed across all developmental stages regardless of species and strain. The sorption of $\mathrm{COS}$ was $10 \%$ higher than that of $\mathrm{PH}_{3}$, but there was no significant difference in rice quality compared to that in the control. Therefore, this study suggests that COS can be used for controlling T. castaneum resistant to $\mathrm{PH}_{3}$.

Keywords: Tribolium castaneum; phosphine resistance; Oryzaephilus surinamensis; phosphine; carbonyl sulfide; fumigation 


\section{Introduction}

Various methods are used in quarantine to prevent the inflow of foreign pests due to increased trade among countries. Fumigation, heat treatment, low-temperature treatment and ionization energy have been researched and used for pest control during quarantine [1-5]. Of these methods, fumigation is widely used in quarantine, especially against stored-product pests, because it is an effective and economical method [6,7]. Methyl bromide (MB) and phosphine $\left(\mathrm{PH}_{3}\right)$ are widely used in pest control for grains and stored foods, but the availability of $\mathrm{MB}$ is limited because it is an ozone-depleting substance, and thus $\mathrm{PH}_{3}$ has been used to control pests in quarantine as an alternative [8,9]. However, $\mathrm{PH}_{3}$ resistance has been reported in Rhyzopertha dominica, Tribolium castaneum, and Sitophilus zeamais, which requires a long treatment time [10-12]. Therefore, due to the increase in $\mathrm{PH}_{3}$-resistant pests, an alternative control agent or control method is necessary. Carbonyl sulfide (COS) was developed in Australia as a fumigant to replace $\mathrm{MB}$ and $\mathrm{PH}_{3}$ and was patented and registered as a grain fumigant in 1993 [13-16]. COS has been studied in regard to its efficacy in controlling Amyelois transitella, Oryzaephilus surinamensis, Carpophilus hemipterus, Lasioderma serricorne, and Tribolium confusum as a substitute for $\mathrm{MB}$ and $\mathrm{PH}_{3}$ to control stored-grain pests [8,17-19].

The red flour beetle, Tribolium castaneum (Coleoptera: Tenebrionidae), is one of the most important insect pests found in stored foods and grains worldwide [20,21], causing food deterioration and contamination through the production of debris and feces [22,23]. The sawtoothed grain beetle, Oryzaephilus surinamensis (Coleoptera: Silvanidae), is also one of the most common pests affecting stored-food products worldwide, causing problems associated with mechanically damaged grains during harvesting and drying [24,25]. In particular, $O$. surinamensis are pests that cause the most serious damage to stored grains and flour [24,26].

T. castaneum and O. surinamensis are important grain pests, damaging $10-40 \%$ of stored crops [27]. Recently, a resistant strain to $\mathrm{PH}_{3}$ has appeared in various stored pests, and many studies on the diagnosis and characterization of $\mathrm{PH}_{3}$-resistant pests have been conducted, with Tribolium castaneum and Oryzaephilus surinamensis among the investigated pests [28-34]. Korea is one of the world's top five grain importers, accounting for $90 \%$ of wheat and corn imports [35]. Therefore, even if the $\mathrm{PH}_{3}$-resistant pest populations have not yet been found in Korea, there is a high possibility of an influx of stored-product $\mathrm{PH}_{3}$-resistant pests from abroad.

This study investigated the effective control of $d$ - and r-strain T. castaneum and O. surinamensis, which are pests of stored grains, by evaluating the effects of $\mathrm{PH}_{3}$ and $\mathrm{COS}$ fumigation. Therefore, the objective of this study was to provide basic data regarding the use of fumigants to control $\mathrm{PH}_{3}$-resistant stored-grain pests.

\section{Materials and Methods}

\subsection{Insects}

Individuals of domestic strain T. castaneum (d-strain) and O. surinamensis were collected from rice mill buildings in Okcheon and Ochang, Chungbuk Province, Republic of Korea. Individuals of the resistant strain T. castaneum (r-strain) were provided by the Plant Quarantine Technology Center, Republic of Korea; this strain originated at Murdoch University, Australia. These stored-grain pests were reared in the laboratory at $26 \pm 1{ }^{\circ} \mathrm{C}$ and $60-70 \%$ relative humidity with a $16: 8 \mathrm{~h}(\mathrm{~L}: \mathrm{D})$ photoperiod. Flour $(800 \mathrm{~g})$, wheat bran $(200 \mathrm{~g})$ and dry yeast $(70 \mathrm{~g})$ were mixed to serve as a food source, and the beetles were reared in plastic containers $(20 \mathrm{~cm} \mathrm{~W} \times 7 \mathrm{~cm} \mathrm{~L} \times 8 \mathrm{~cm} \mathrm{H})$.

\subsection{Fumigants}

Phosphine $\left(2 \% \mathrm{PH}_{3}+98 \% \mathrm{CO}_{2}\right)$ and carbonyl sulfide $\left(97.5 \% \mathrm{COS}+2.5 \% \mathrm{CO}_{2}\right)$ were purchased from Korea Nano Gas Co. (Yeoju, Korea). 


\subsection{Fumigation Experiments}

The fumigation activities against all developmental stages of T. castaneum (d- and r-strain) and O. surinamensis were investigated using $\mathrm{PH}_{3}$ and $\mathrm{COS}$ in a 12-L desiccator and $0.5 \mathrm{~m}^{3}$ fumigation chamber modified according to Kyung et al. [36].

Twenty individuals of each developmental stage of the 3 kinds of stored-grain pests were placed in a Petri dish $\left(5 \mathrm{~cm}\right.$ i.d. $\times 1 \mathrm{~cm}$ ) containing $0.05 \mathrm{~g}$ of food in a 12-L desiccator. $\mathrm{PH}_{3}$ and COS were injected using $100 \mathrm{~mL}$ and $500 \mathrm{~mL}$ gastight syringes (Hamilton, NV, USA), respectively. The d-, and r-strain T. castaneum and O. surinamensis were exposed to $\mathrm{PH}_{3}$ at various doses for $4 \mathrm{~h}$, while the r-strain T. castaneum were exposed to $\mathrm{PH}_{3}$ at $2 \mathrm{mg} / \mathrm{L}$ for $24 \mathrm{~h}$ to $250 \mathrm{~h}$ of exposure. The COS treatment was conducted with $24 \mathrm{~h}$ of exposure to all stored grain pests. The fumigation treatment was applied at $20 \pm 1{ }^{\circ} \mathrm{C}$, and the dishes were incubated at $26 \pm 1^{\circ} \mathrm{C}$ and $60-70 \%$ relative humidity with a $16: 8 \mathrm{~h}(\mathrm{~L}: \mathrm{D})$ photoperiod after treatment. The controls were not treated with any fumigants.

Each Petri dish $(5 \mathrm{~cm})$ containing each developmental stage of the stored-grain pests was placed in a $0.5 \mathrm{~m}^{3}$ fumigation chamber $(125 \times 50 \times 80 \mathrm{~cm})$ at a loading ratio of $50 \%$ with rice. The Petri dishes were placed in the top, middle and bottom parts of the chamber, respectively. The $\mathrm{PH}_{3}$ and COS treatments were administered at $2 \mathrm{~g} / \mathrm{m}^{3}$ and $50 \mathrm{~g} / \mathrm{m}^{3}$, respectively, with $24 \mathrm{~h}$ of exposure, except in the case of r-strain T. castaneum, which was exposed to $\mathrm{PH}_{3}$ for $192 \mathrm{~h}$.

All experiments were repeated 3 times, and mortality was evaluated 13 days after treatment for larvae, pupae and adults and 20 days after treatment for the egg stage.

\subsection{Gas Concentration and Sorption Measurements}

The gas concentration in each fumigation chamber was measured with a Tedlar gas sampling bag (1 L, SKC, Dorset, UK) using a gastight syringe $(100 \mu \mathrm{L}$, Hamilton, NV, USA). The collected gas concentration was analyzed with gas chromatography (GC) (Agilent Technology 6890N, and 7890A, Santa Clara, CA, USA). The detector used for $\mathrm{PH}_{3}$ was a nitrogen phosphorus detector (NPD), and that used for COS was a flame photometric detector (FPD). The GC conditions were as follows: The GC NPD injector temperature was $250{ }^{\circ} \mathrm{C}$, the oven temperature was $240{ }^{\circ} \mathrm{C}$, the detector temperature was $320^{\circ} \mathrm{C}$, and the column was an HP-5 (0.53 mm $\times 15 \mathrm{~m}$, Agilent Technology, Santa Clara, CA, USA) operating in splitless mode. The FPD had an injector temperature of $200{ }^{\circ} \mathrm{C}$, detector temperature of $200^{\circ} \mathrm{C}$ and oven temperature of $200{ }^{\circ} \mathrm{C}$, and the column was a DB-Sulfur SCD $(0.53 \mathrm{~mm} \times 70 \mathrm{~m}$, Agilent Technology, Santa Clara, CA, USA).

The concentration and time (CT) values were determined by collecting gases at 30 min and 1, 4, 8, 12, and $24 \mathrm{~h}$ after treatment with $\mathrm{PH}_{3}$ and COS, and gas was collected until 48, 96, and $192 \mathrm{~h}$ had passed for $\mathrm{PH}_{3}$ in $0.5 \mathrm{~m}^{3}$ fumigation chamber (AFHB/ACIA, 1989).

The sorption rates of $\mathrm{PH}_{3}$ and COS were determined using a 12-L desiccator with $0 \%$ and $50 \%$ loading ratios $(w / v)$ with rice. $\mathrm{PH}_{3}$ and COS were applied at doses of $2 \mathrm{mg} / \mathrm{L}$ and $50 \mathrm{mg} / \mathrm{L}$, respectively, at $20^{\circ} \mathrm{C}$ for $24 \mathrm{~h}$. The gas concentration for sorption was determined at $1,4,8,12,18$ and $24 \mathrm{~h}$ after treatment and analyzed following the GC conditions described above. $C / C_{0}(\%)$ values were calculated as the concentration at each time after treatment $(C)$ divided by the initial concentration 30 min after treatment $\left(C_{0}\right)$ and multiplied by 100 . A 12-L desiccator without rice was used as the control.

\subsection{Rice Quality Evaluation}

The rice quality was evaluated to determine the effects of the two fumigants on rice. Either $2 \mathrm{~g} / \mathrm{m}^{3}$ $\mathrm{PH}_{3}$ or $50 \mathrm{~g} / \mathrm{m}^{3}$ COS was applied in the $0.5 \mathrm{~m}^{3}$ fumigation chamber at a loading ratio of $50 \%$ with rice for $48 \mathrm{~h}$ of exposure, and then rice quality was measured $24 \mathrm{~h}$ after treatment. The control was not treated with any fumigants.

Rice quality was analyzed by collecting $1 \mathrm{~kg}$ of rice from each treatment. As a component analysis, the protein and amylose content in $300 \mathrm{~g}$ of rice were measured using an Infratec ${ }^{\mathrm{TM}} 1241$ grain analyzer (Foss, Hilleroed, Denmark). Measurement of the physical change ratio (\%) was carried out with 
1000 grains of head rice, broken rice, chalky kernels, and damaged rice using a Single-Grain Rice Inspector, model RN-600 (Kett Electric Laboratory, Tokyo, Japan). All measurements were conducted at Chungcheongbuk-do Agricultural Research and Extension Services (Cheongju, Korea).

\subsection{Statistical Analysis}

The fumigation activities of $\mathrm{PH}_{3}$ and $\mathrm{COS}$ against T. castaneum (d-strain and r-strain) and O. surinamensis were analyzed statistically according to the doses and locations, and the exposure times of the r-strain T. castaneum were also compared using Tukey's test [37]. The differences in rice quality between the fumigant-treated and untreated rice were analyzed using a $t$-test [37].

\section{Results}

\subsection{Fumigation Activities of $\mathrm{PH}_{3}$ and COS in a 12-LDesiccator}

The fumigation activities were investigated after the exposure of d-strain T. castaneum, r-strain T. castaneum and O. surinamensis to $\mathrm{PH}_{3}$ for $4 \mathrm{~h}$ (Figure 1). Exposure for $4 \mathrm{~h}$ was not sufficient to control $100 \%$ of d- or $\mathrm{r}$-strain T. castaneum. Specifically, the r-strain T. castaneum showed very low susceptibility across all developmental stages. However, the r-strain did not show $100 \%$ mortality after $24 \mathrm{~h}$ of exposure (data not shown), but the $\mathrm{d}$-strain $\mathrm{T}$. castaneum exhibited $100 \%$ fumigant activity across all developmental stages under these conditions (Figure 2). In particular, the egg stage showed the lowest mortality of $2.9 \%$ after $24 \mathrm{~h}$ of exposure to $2 \mathrm{mg} / \mathrm{L}$, and all r-strain T. castaneum developmental stages showed $100 \%$ mortality only when exposed to this amount for $192 \mathrm{~h}$. The egg and pupal stages did not show $100 \%$ mortality in the $1 \mathrm{mg} / \mathrm{L} \mathrm{PH}_{3}$ treatment, but all developmental stages of O. surinamensis showed $>98 \%$ mortality (99.2\% in egg, $98.3 \%$ in pupa, and $100 \%$ in larvae and adult stage, respectively) when exposed to $2 \mathrm{mg} / \mathrm{L}$ of the $\mathrm{PH}_{3}$ treatment for $4 \mathrm{~h}$.
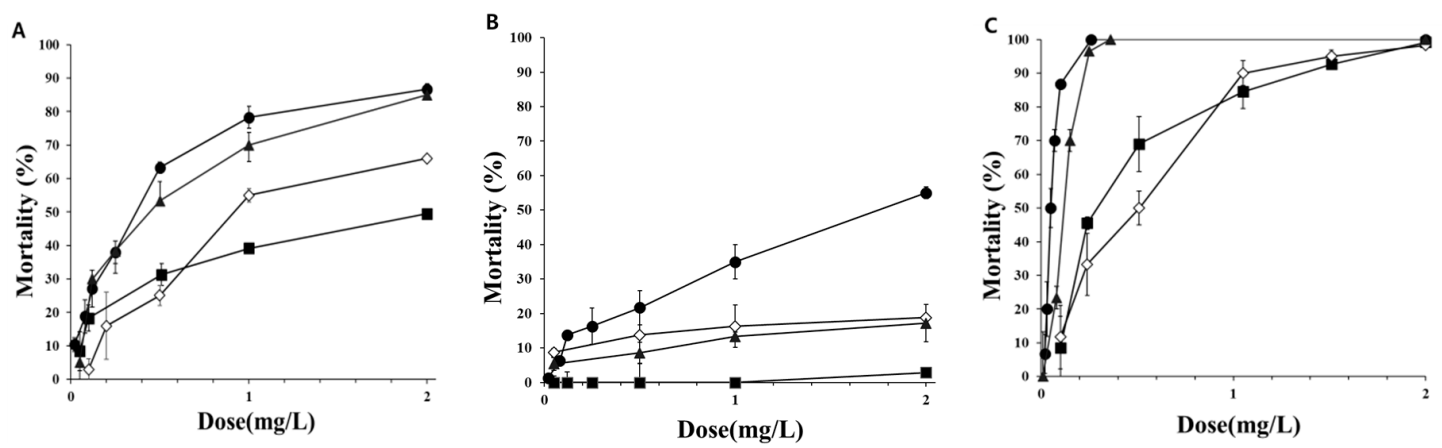

$\neg$ Egg $\rightarrow$ Larva $\prec$ Pupa $\leftarrow$ Adult

Figure 1. Mortality of (A), d-strain Tribolium castaneum, (B), r-strain T. castaneum and (C), Oryzaephilus surinamensis eggs, larvae, pupae and adults after $4 \mathrm{~h}$ of exposure to the $\mathrm{PH}_{3}$ fumigant in a 12-L desiccator.

After $24 \mathrm{~h}$ of exposure to various doses of fumigation with COS, mortality was evaluated in d-strain T. castaneum, r-strain T. castaneum and O. surinamensis (Figure 3). Treatment with COS had similar results in both d-strain and r-strain $T$. castaneum. The d-strain $T$. castaneum adults and larvae showed $100 \%$ mortalities at $14 \mathrm{mg} / \mathrm{L}$ and $25 \mathrm{mg} / \mathrm{L}$, respectively, and the same percentage of activity was observed in r-strain T. castaneum at $12 \mathrm{mg} / \mathrm{L}$ and $17 \mathrm{mg} / \mathrm{L}$. The eggs and pupae of both strains showed $100 \%$ mortality only when $30 \mathrm{mg} / \mathrm{L}$ of COS was used. Although the fumigation activity detected in COS-treated eggs and pupae was lower than that in other developmental stages, fumigant activity was observed regardless of the strain. O. surinamensis showed 100\% mortality in adult, larva and pupa stages at $20 \mathrm{mg} / \mathrm{L}$, but $100 \%$ mortality was observed in the egg stage at $40 \mathrm{mg} / \mathrm{L}$. 


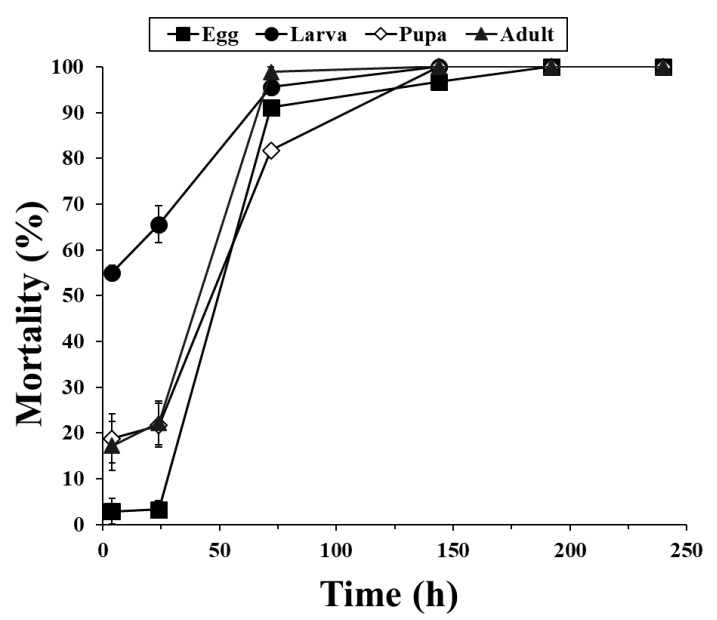

Figure 2. Mortality of r-strain Tribolium castaneum across all developmental stages after treatment with $2 \mathrm{mg} / \mathrm{L} \mathrm{PH}_{3}$ in a 12-L desiccator according to exposure time.
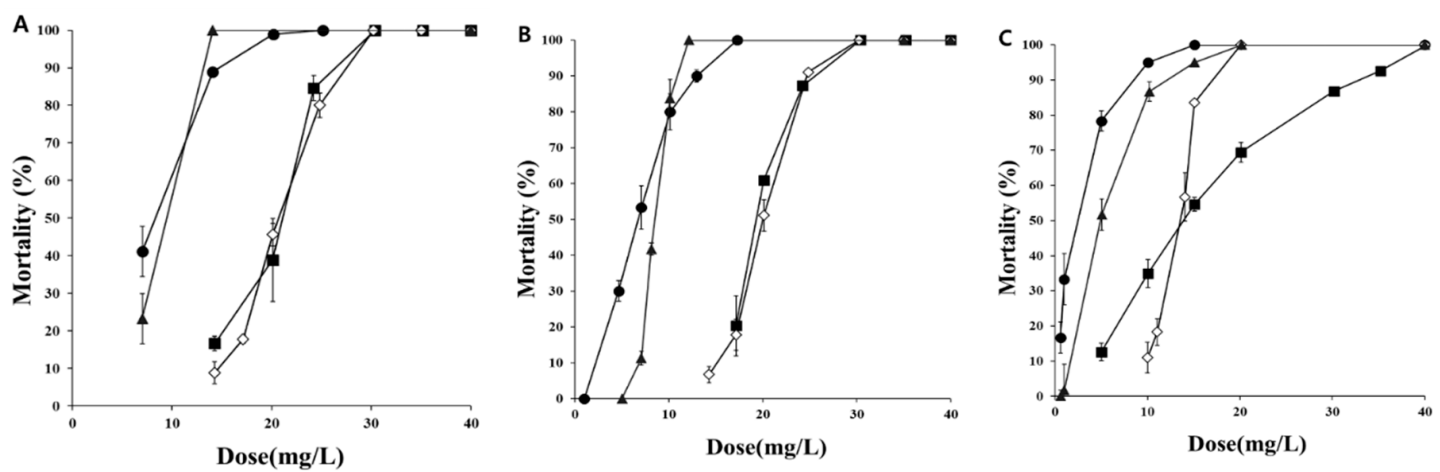

$\rightarrow$ Egg $\rightarrow$ Larva $\leadsto$-Pupa $\leftarrow$ Adult

Figure 3. Mortality of (A), d-strain Tribolium castaneum, (B), r-strain T. castaneum and (C), Oryzaephilus surinamensis eggs, larvae, pupae and adults after $24 \mathrm{~h}$ of exposure to the carbonyl sulfide (COS) fumigant in a 12-L desiccator.

\subsection{Scale-Up Fumigation Experiment with $\mathrm{PH}_{3}$ and $\mathrm{COS}$ in a $0.5 \mathrm{~m}^{3}$ Fumigation Chamber}

In the $0.5 \mathrm{~m}^{3}$ fumigation chamber experiment, when d-strain T. castaneum and O. surinamensis were treated with $2 \mathrm{~g} / \mathrm{m}^{3} \mathrm{PH}_{3}$ for $24 \mathrm{~h}$ at a $50 \%$ loading ratio with rice, all developmental stages showed $100 \%$ mortality regardless of the location (Table 1 ). However, the r-strain T. castaneum larvae showed less than 70\% mortality only following 24-h exposure to $\mathrm{PH}_{3}$, and the other developmental stages showed very low fumigation activities $(<29 \%)$. When the time of exposure to $\mathrm{PH}_{3}$ was increased to $192 \mathrm{~h}, 100 \%$ mortality was observed across all developmental stages of $\mathrm{r}$-strain $T$. castaneum at all locations.

The fumigation activity of COS was investigated after $24 \mathrm{~h}$ of exposure in the $0.5 \mathrm{~m}^{3}$ fumigation chamber for d-strain T. castaneum, r-strain T. castaneum and O. surinamensis (Table 2). The d-strain T. castaneum, r-strain T. castaneum and O. surinamensis exposed to $50 \mathrm{~g} / \mathrm{m}^{3}$ of COS for $24 \mathrm{~h}$ showed $100 \%$ mortality regardless of location. 
Table 1. Fumigant activity of $2 \mathrm{~g} / \mathrm{m}^{3} \mathrm{PH}_{3}$ at each location in a $0.5 \mathrm{~m}^{3}$ fumigation chamber containing rice at a $50 \%$ loading ratio.

\begin{tabular}{|c|c|c|c|c|c|c|}
\hline Exposure Time(h) & Species/Strain & Stages & $n$ & Locate & Mortality & CT Value $\left(\mathrm{g} \cdot \mathrm{h} / \mathrm{m}^{3}\right)$ \\
\hline \multirow{48}{*}{24} & \multirow{16}{*}{ O. surinamensis } & \multirow{4}{*}{ Egg } & 283 & Top & $100 \pm 0.0 \mathrm{a}$ & \multirow{48}{*}{39.40} \\
\hline & & & 284 & Middle & $100 \pm 0.0 \mathrm{a}$ & \\
\hline & & & 286 & Bottom & $100 \pm 0.0 \mathrm{a}$ & \\
\hline & & & 285 & Control & $4.9 \pm 2.7 \mathrm{~b}$ & \\
\hline & & \multirow{4}{*}{ Larva } & 290 & Top & $100 \pm 0.0 \mathrm{a}$ & \\
\hline & & & 268 & Middle & $100 \pm 0.0 \mathrm{a}$ & \\
\hline & & & 291 & Bottom & $100 \pm 0.0 \mathrm{a}$ & \\
\hline & & & 278 & Control & $3.6 \pm 0.9 b$ & \\
\hline & & \multirow{4}{*}{ Pupa } & 271 & Top & $100 \pm 0.0 \mathrm{a}$ & \\
\hline & & & 281 & Middle & $100 \pm 0.0 \mathrm{a}$ & \\
\hline & & & 279 & Bottom & $100 \pm 0.0 \mathrm{a}$ & \\
\hline & & & 280 & Control & $5.8 \pm 4.0 \mathrm{~b}$ & \\
\hline & & \multirow{4}{*}{ Adult } & 283 & Top & $100 \pm 0.0 \mathrm{a}$ & \\
\hline & & & 291 & Middle & $100 \pm 0.0 \mathrm{a}$ & \\
\hline & & & 290 & Bottom & $100 \pm 0.0 \mathrm{a}$ & \\
\hline & & & 288 & Control & $5.3 \pm 0.8 b$ & \\
\hline & \multirow{16}{*}{ T. castaneumd-strain } & \multirow{4}{*}{ Egg } & 296 & Top & $100 \pm 0.0 \mathrm{a}$ & \\
\hline & & & 296 & Middle & $100 \pm 0.0 \mathrm{a}$ & \\
\hline & & & 293 & Bottom & $100 \pm 0.0 \mathrm{a}$ & \\
\hline & & & 294 & Control & $9.4 \pm 0.8 b$ & \\
\hline & & \multirow{4}{*}{ Larva } & 270 & Top & $100 \pm 0.0 \mathrm{a}$ & \\
\hline & & & 275 & Middle & $100 \pm 0.0 \mathrm{a}$ & \\
\hline & & & 280 & Bottom & $100 \pm 0.0 \mathrm{a}$ & \\
\hline & & & 270 & Control & $5.0 \pm 1.5 b$ & \\
\hline & & \multirow{4}{*}{ Pupa } & 270 & Top & $100 \pm 0.0 a$ & \\
\hline & & & 270 & Middle & $100 \pm 0.0 \mathrm{a}$ & \\
\hline & & & 270 & Bottom & $100 \pm 0.0 \mathrm{a}$ & \\
\hline & & & 270 & Control & $7.3 \pm 1.1 \mathrm{~b}$ & \\
\hline & & \multirow{4}{*}{ Adult } & 270 & Top & $100 \pm 0.0 \mathrm{a}$ & \\
\hline & & & 270 & Middle & $100 \pm 0.0 \mathrm{a}$ & \\
\hline & & & 270 & Bottom & $100 \pm 0.0 \mathrm{a}$ & \\
\hline & & & 270 & Control & $3.3 \pm 0.6 b$ & \\
\hline & \multirow{16}{*}{ T. castaneumr-strain } & & 301 & Top & $3.3 \pm 1.9 a$ & \\
\hline & & $\mathrm{Fog}$ & 292 & Middle & $5.5 \pm 1.2 \mathrm{a}$ & \\
\hline & & Egg & 276 & Bottom & $7.6 \pm 1.0 \mathrm{a}$ & \\
\hline & & & 278 & Control & $4.7 \pm 1.4 \mathrm{~b}$ & \\
\hline & & & 279 & Top & $61.2 \pm 2.8 a$ & \\
\hline & & & 274 & Middle & $67.1 \pm 1.9 a$ & \\
\hline & & Larva & 278 & Bottom & $65.8 \pm 4.2 \mathrm{a}$ & \\
\hline & & & 281 & Control & $3.6 \pm 1.6 b$ & \\
\hline & & & 297 & Top & $25.9 \pm 1.8 \mathrm{a}$ & \\
\hline & & Puna & 296 & Middle & $24.0 \pm 3.5 a$ & \\
\hline & & & 291 & Bottom & $21.7 \pm 3.7 \mathrm{a}$ & \\
\hline & & & 291 & Control & $7.2 \pm 1.2 b$ & \\
\hline & & & 273 & Top & $28.3 \pm 5.1 \mathrm{a}$ & \\
\hline & & & 284 & Middle & $27.0 \pm 4.3 \mathrm{a}$ & \\
\hline & & Adult & 281 & Bottom & $23.2 \pm 3.9 a$ & \\
\hline & & & 286 & Control & $5.3 \pm 1.9 b$ & \\
\hline & & & 285 & Top & $100 \pm 0.0 \mathrm{a}$ & \\
\hline & & $\mathrm{Fgg}$ & 277 & Middle & $100 \pm 0.0 \mathrm{a}$ & \\
\hline & & Egg & 300 & Bottom & $100 \pm 0.0 \mathrm{a}$ & \\
\hline & & & 279 & Control & $1.8 \pm 0.8 \mathrm{~b}$ & \\
\hline & & & 305 & Top & $100 \pm 0.0 \mathrm{a}$ & \\
\hline & & & 285 & Middle & $100 \pm 0.0 \mathrm{a}$ & \\
\hline & & Larva & 281 & Bottom & $100 \pm 0.0 \mathrm{a}$ & \\
\hline 192 & T. castaneumr-strain & & 273 & Control & $7.3 \pm 3.1 b$ & 261.31 \\
\hline & & & 300 & Top & $100 \pm 0.0 \mathrm{a}$ & \\
\hline & & Puna & 300 & Middle & $100 \pm 0.0 \mathrm{a}$ & \\
\hline & & Pupa & 300 & Bottom & $100 \pm 0.0 \mathrm{a}$ & \\
\hline & & & 288 & Control & $7.7 \pm 1.3 b$ & \\
\hline & & & 291 & Top & $100 \pm 0.0 \mathrm{a}$ & \\
\hline & & & 284 & Middle & $100 \pm 0.0 \mathrm{a}$ & \\
\hline & & Adult & 279 & Bottom & $100 \pm 0.0 \mathrm{a}$ & \\
\hline & & & 280 & Control & $8.1 \pm 2.6 b$ & \\
\hline
\end{tabular}

Mortality (\%, mean \pm SE), followed by the different letter within columns, was significantly different at $p<0.05$ by Tukey's test (SAS Institute 2009). 
Table 2. Fumigant activity of $50 \mathrm{~g} / \mathrm{m}^{3} \mathrm{COS}$ at each location in a $0.5 \mathrm{~m}^{3}$ fumigation chamber containing rice at a $50 \%$ loading ratio.

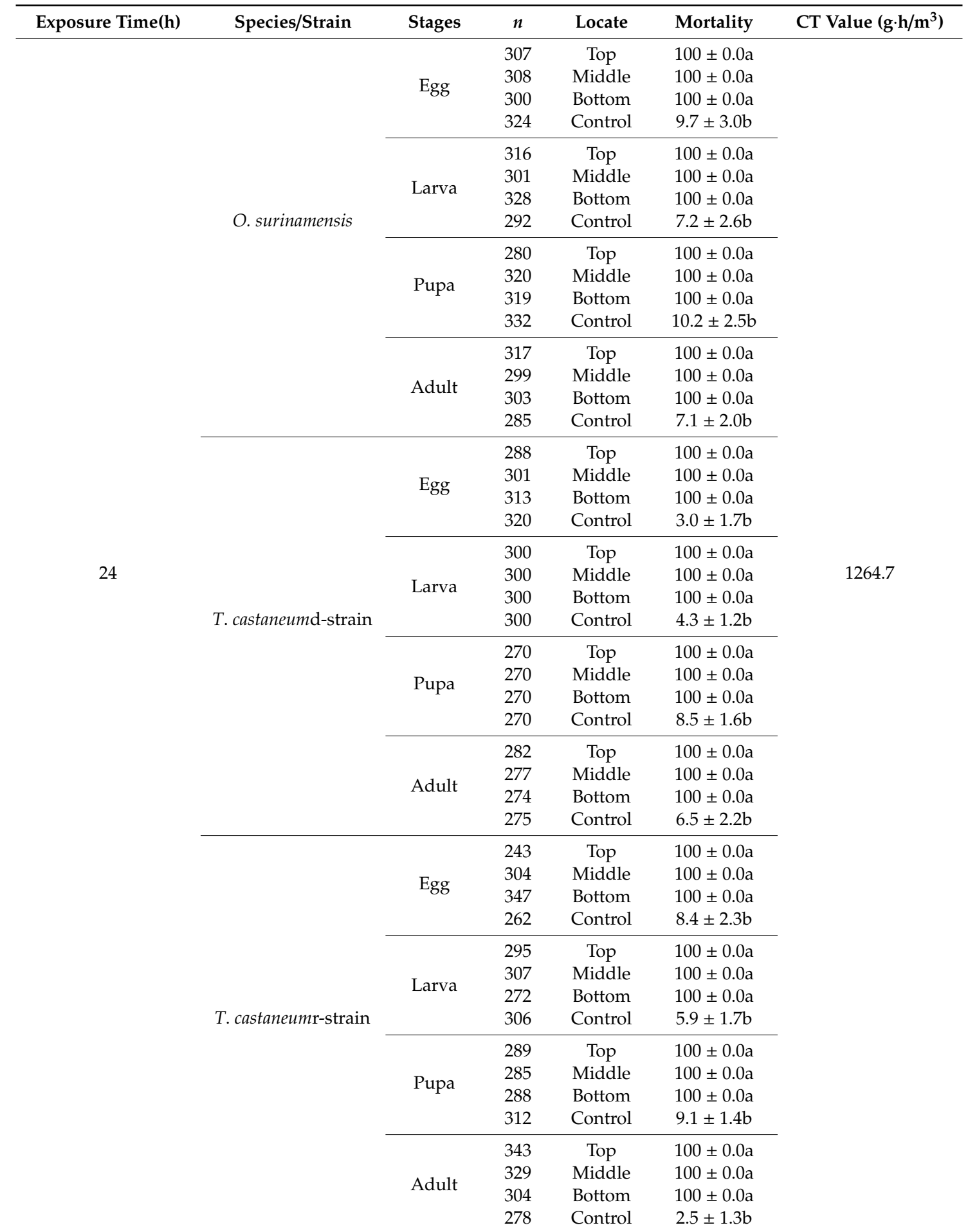

Mortality (\%, mean \pm SE), followed by the different letter within columns, was significantly different at $p<0.05$ by Tukey's test (SAS Institute 2009).

\subsection{Rice Quality and Sorption of the Two Fumigants}

Six rice quality experiments under exposure to $\mathrm{PH}_{3}$ and $\mathrm{COS}$ were conducted in a 12-L desiccator (Table 3). The changes in protein content and amylose, which are components of rice, did not show 
any statistically significant differences compared to those in the control for both fumigants. The two fumigants did not affect the rice in terms of the four kinds of physical change rates.

Table 3. Quality of rice exposed to $2 \mathrm{~g} / \mathrm{m}^{3} \mathrm{PH}_{3}$ and $50 \mathrm{~g} / \mathrm{m}^{3} \mathrm{COS}$ at a $50 \%$ loading ratio following $48 \mathrm{~h}$ of exposure in a $0.5 \mathrm{~m}^{3}$ fumigation chamber.

\begin{tabular}{cccccc}
\hline Quality Criteria $^{\mathbf{a}}$ & Control & $\mathbf{P H}_{\mathbf{3}}$ & $p$-Value & $\mathbf{C O S}$ & $p$-Value \\
\hline Protein content & $5.60 \pm 0.00 \mathrm{a}$ & $5.53 \pm 0.03 \mathrm{a}$ & 0.12 & $5.60 \pm 0.00 \mathrm{a}$ & - \\
\hline Amylose content & $13.77 \pm 0.0 \mathrm{a}$ & $14.01 \pm 0.06 \mathrm{a}$ & 0.03 & $13.80 \pm 0.03 \mathrm{a}$ & 0.35 \\
\hline Head rice ratio & $76.80 \pm 1.36 \mathrm{a}$ & $76.0 \pm 1.20 \mathrm{a}$ & 0.68 & $76.6 \pm 1.37 \mathrm{a}$ & 0.92 \\
\hline Broken rice ratio & $1.37 \pm 0.23 \mathrm{a}$ & $1.53 \pm 0.35 \mathrm{a}$ & 0.75 & $0.90 \pm 0.00 \mathrm{a}$ & 0.32 \\
\hline Chalky rice ratio & $7.07 \pm 0.38 \mathrm{a}$ & $7.67 \pm 0.37 \mathrm{a}$ & 0.32 & $6.67 \pm 0.61 \mathrm{a}$ & 0.91 \\
\hline Damaged rice ratio & $14.83 \pm 1.18 \mathrm{a}$ & $12.97 \pm 0.92 \mathrm{a}$ & 0.39 & $15.8 \pm 0.80 \mathrm{a}$ & 0.52 \\
\hline
\end{tabular}

${ }^{a}$ A $t$-test was used to compare values $(\%$, mean $\pm \mathrm{SE}$ ) of each rice quality criteria between control and treated fumigants.

The sorption rates of rice following exposure to $\mathrm{PH}_{3}$ and $\mathrm{COS}$ for up to $24 \mathrm{~h}$ were analyzed (Figure 4). After $5 \mathrm{~h}$ of treatment of a $50 \%$ loading ratio of rice with $2 \mathrm{mg} / \mathrm{L} \mathrm{PH}_{3}$, the concentration began to decrease to $96 \%$, and the concentration was $91 \%$ after $24 \mathrm{~h}$ of treatment. When the $50 \%$ loading ratio of rice was treated with $50 \mathrm{mg} / \mathrm{L} \mathrm{COS}$, the concentration began to decrease to $97 \%$ after $1 \mathrm{~h}$ and decreased to $82 \%$ after $24 \mathrm{~h}$. However, $\mathrm{PH}_{3}$ and $\mathrm{COS}$ did not show a significant reduction in concentration ( $97 \%$ and $98 \%$, respectively), even after $24 \mathrm{~h}$ of treatment, in the control without rice.
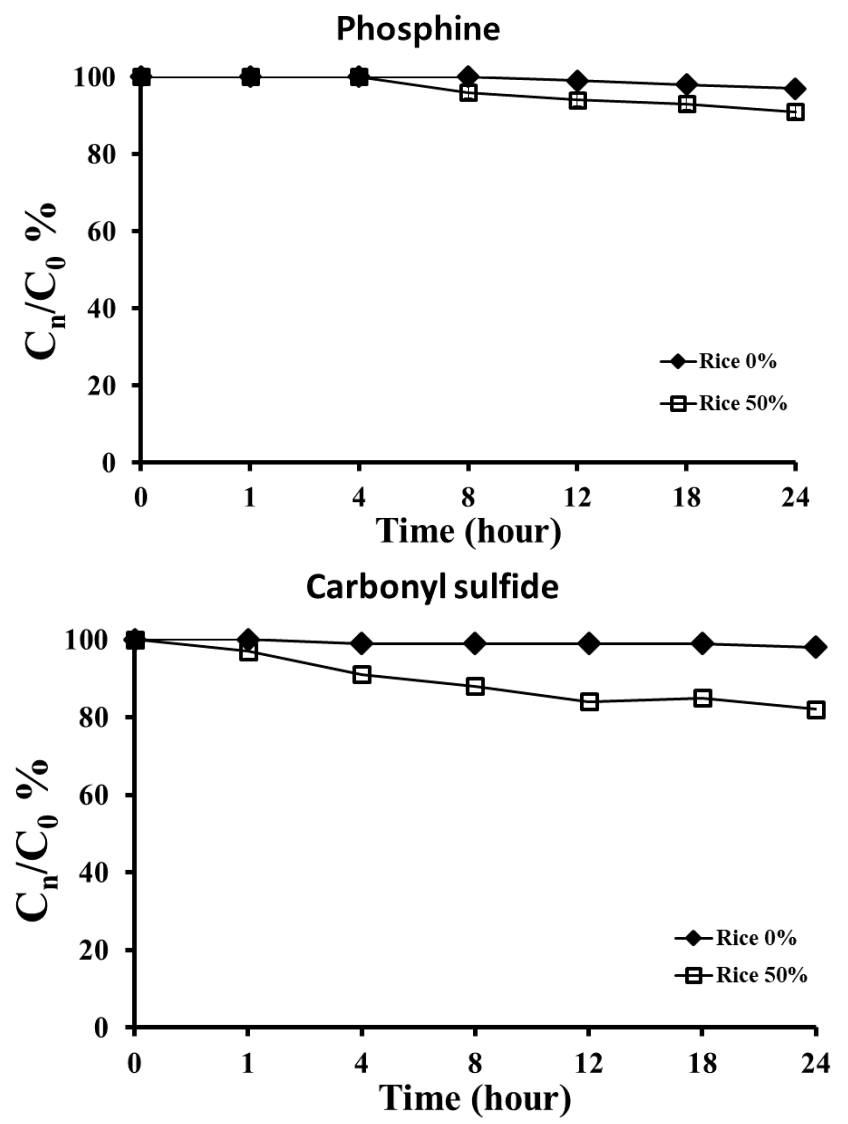

Figure 4. Concentrations of the two fumigants $\left(2 \mathrm{mg} / \mathrm{L} \mathrm{PH}_{3}\right.$ and $\left.50 \mathrm{mg} / \mathrm{L} \mathrm{COS}\right)$ at $20{ }^{\circ} \mathrm{C}$ according to the loading ratio $(0 \%$ and $50 \%)$ of rice for $24 \mathrm{~h}$ in a $12-\mathrm{L}$ desiccator. 


\section{Discussion}

This study evaluated the activity of $\mathrm{PH}_{3}$ and $\mathrm{COS}$ against two stored-product pests, T. castaneum (d-strain and r-strain) and O. surinamensis. $\mathrm{PH}_{3}$ shows fumigation activity against various grain pests, T. castaneum, Rhyzopertha dominica, and O. surinamensis, but an increase in the resistant strain of these insects has been reported [11,38-40]. This experiment was performed to investigate an alternative fumigant that is effective against $\mathrm{PH}_{3}$-resistant pests, especially T. castaneum. This is because T. castaneum has a very high frequency of strong resistance to $\mathrm{PH}_{3}$, especially in the United States, Southern India and Turkey [11,29,30]. Although it has been reported that sulfuryl fluoride (SF) has the effect of controlling $\mathrm{PH}_{3}$-resistant pests, it is vulnerable to low temperatures and has a disadvantage in that it is not easy to use because there is a change in activity according to sealing techniques during treatment [41]. COS is also toxic to stored-grain pests such as T. castaneum, R. dominica, O. surinamensis, Callosobruchus chinensis, Sitophilus zeamais, Lasioderma serricorne, Cryptolestes pusillus, Callosobruchus maculatus, Trogoderma variable, and Tribolium confusum $[14,42]$. This experiment also showed fumigation activity against T. castaneum and O. surinamensis. Ther-strain T. castaneum treated with $\mathrm{PH}_{3}$ showed an increasing fumigation effect only when the exposure time was increased because the fumigation effect was much lower than that observed ford-strain T. castaneum, but both the d- and r-strains of T. castaneum showed similar results in the COS treatment. It was also observed that the COS showed higher tolerance to O. surinamensis than in d-and r-strains of T. castaneum at the egg stage. This is because of the difference in the target site where $\mathrm{PH}_{3}$ and COS exhibit toxicity; $\mathrm{PH}_{3}$ is toxic because of the formation of reactive oxygen radicals involved in the electron transport chain, and COS is toxic because of the metabolite action of hydrogen sulfide [43-45]. The fumigation activity of both fumigants differed according to the developmental stage exposed. A similar effect has also been observed in association with other pests and fumigants. Under $4 \mathrm{~h}$ of exposure, Frankliniella occidentalis eggs showed higher tolerance to the fumigation activity of $>16 \mathrm{mg} \cdot \mathrm{h} / \mathrm{L} \mathrm{PH}_{3}$ at $5{ }^{\circ} \mathrm{C}$ and $>84.4 \mathrm{mg} \cdot \mathrm{h} / \mathrm{L}$ ethyl formate $(\mathrm{EF})$ at $5{ }^{\circ} \mathrm{C}$ than other developmental stages [36]. In addition, Phthorimaea operculella larvae and eggs showed the highest tolerance during $\mathrm{PH}_{3}$ treatment, and Carposina niponensis and Rhynchophorus ferrugineus showed the highest tolerance in the egg stage [46-48]. In this study, a difference in fumigation activity to each developmental stage was also observed, but the fumigation effect decreased in the egg and pupa stage in d- and r-strain T. castaneum and O. surinamensis for both fumigants. Even in the scale-up experiment $\left(0.5 \mathrm{~m}^{3}\right)$ in which the dose was set based on the results of the 12-L desiccator experiment, the $\mathrm{PH}_{3} \mathrm{r}$-strains of T. castaneum showed $100 \%$ mortality for 192-h exposure, but all three kinds of stored pests could be controlled $100 \%$ at the same dose in the COS treatment. Thus, even when scaling-up at the field level, it is thought that fumigation activity against pests will be observed at the COS dose $\left(50 \mathrm{~g} / \mathrm{m}^{3}\right)$ used inthis study.

In terms of the adsorption rate, that of COS was higher than that of $\mathrm{PH}_{3}$, but it did not affect the fumigation activity in the 24-h exposure treatment. The use of COS did not have obvious side effects, such as water adsorption by rice, the expansion of cooking rice or dry substances in the rice cooking water, but the flavor changed when a COS concentration of more than $100 \mathrm{~g} / \mathrm{m}^{3}$ was used [42]. Furthermore, in the rice quality evaluation in this study, both fumigants did not result in any significant difference in quality compared to that ofthe control, even in the treatment of $50 \mathrm{~g} / \mathrm{m}^{3} \mathrm{COS}$.

These results indicate that $\mathrm{PH}_{3}$ is a very effective fumigant for the control of stored-grain pests and that COS could be used an alternative for the control of the T. castaneum strain resistant to $\mathrm{PH}_{3}$ and O. surinamensis.

\section{Conclusions}

In our evaluation of the fumigation activity of $\mathrm{PH}_{3}$ against $\mathrm{d}$ - and r-strain $\mathrm{T}$. castaneum and O. surinamensis, it was found that r-strain T. castaneum has very high resistance to $\mathrm{PH}_{3}$. However, in the COS treatment, r-strain T. castaneum showed similar mortality to that of d-strain T. castaneum. Ifr-strain T. castaneum appears during the control of stored-grain pests, it is worth considering the use of COS as an alternative to $\mathrm{PH}_{3}$. 
Author Contributions: Investigation, H.K.L. and G.J.; formal analysis and writing-original draft preparation, H.K.K.; resources, B.-S.K. and J.-O.Y.; validation, H.-N.K.; supervision, G.-H.K. All authors have read and agreed to the published version of the manuscript.

Funding: This research received funding from the Animal and Plant Quarantine Agency, Korea (grant no. PQ20180B029).

Acknowledgments: The authors would like to thank Yonglin Ren for supporting us with the resistance strain T. castaneum.

Conflicts of Interest: The authors declare no conflict of interest.

\section{References}

1. Follett, P.A.; Neven, L.G. Current trends in quarantine entomology. Annu. Rev. Entomol. 2006, 51, 359-385. [CrossRef] [PubMed]

2. Heather, N.W.; Hallman, G.J. Agricultural warfare and bioterrorism using invasive species. In Pest Management and Phytosanitary Trade Barriers, 1st ed.; CABI Publishing: Wallingford, UK, 2008; pp. 14-19.

3. Hallman, G.J. Process control in phytosanitary irradiation of fresh fruits and vegetables as a model for other phytosanitary treatment processes. Food Control 2017, 72, 372-377. [CrossRef]

4. Cho, W.S.; Koo, H.N.; Yun, S.H.; Lee, J.S.; Jeong, D.H.; Kang, W.J.; Lee, S.J.; Kim, H.K.; Han, J.H.; Kwon, Y.D.; et al. Electron beam-induced sterility and inhibition of ovarian development in the sakhalin pine longicorn, Monochamus saltuarius (Coleoptera: Cerambycidae). J. Econ. Entomol. 2018, 111, 725-731. [CrossRef] [PubMed]

5. Kyung, Y.J.; Kim, H.K.; Cho, S.W.; Kim, B.S.; Yang, J.O.; Koo, H.N.; Kim, G.H. Comparison of the efficacy and phytotoxicity of phosphine and ethyl formate for controlling Pseudococcus longispinus (Hemiptera: Pseudococcidae) and Pseudococcus orchidicola on imported foliage nursery plants. J. Econ. Entomol. 2019, 112, 2149-2156. [CrossRef]

6. Bond, E.J. Manual of fumigation for insect control. In FAO Plant Production and Protection Paper No. 54; FAO: Rome, Italy, 1984.

7. Chaudhry, M.Q. Phosphine resistance. Pestic. Outlook 2000, 11, 88-91. [CrossRef]

8. Zettler, J.L.; Arthur, F.H. Chemical control of stored product insects with fumigants and residual treatments. Crop Prot. 2000, 19, 577-582. [CrossRef]

9. UNEP (United Nations Environment Programme). Handbook for the Montreal Protocol on Substances That Deplete the Ozone Layer, 7th ed.; UNEP: Nairobi, Kenya, 2006.

10. Daglish, G.J. Effect of exposure period on degree of dominance of phosphine resistance in adults of Rhyzopertha dominica (Coleoptera: Bostrychidae) and Sitophilus oryzae (Coleoptera: Curculionidae). Pest Manag. Sci. 2004, 60, 822-826. [CrossRef]

11. Opit, G.P.; Phillips, T.W.; Aikins, M.J. Phosphine resistance in Tribolium castaneum and Rhyzopertha dominica from stored wheat in Oklahoma. J. Econ. Entomol. 2012, 105, 1107-1114. [CrossRef]

12. Konemann, C.E.; Hubhachen, Z.; Opit, G.P.; Gautam, S.; Bajracharya, N.S. Phosphine resistance in Cryptolestes ferrugineus (Coleoptera: Laemophloeidae) collected from grain storage facilities in Oklahoma, USA. J. Econ. Entomol. 2017, 110, 1377-1383. [CrossRef]

13. Desmarchelier, J.M. Grain protectants: Trends and developments. In Stored Product Protection; Highley, E., Wright, E.J., Banks, H.J., Champ, B.R., Eds.; CAB International: Wallingford, UK, 1994; pp. 722-728.

14. Zettler, J.L.; Leesch, J.G.; Gill, R.F.; Mackey, B.E. Toxicity of carbonyl sulfide to stored product insects. J. Econ. Entomol. 1997, 90, 832-836. [CrossRef]

15. Desmarchelier, J.M.; Allen, S.E.; Ren, Y.; Moss, R.; Vu, L.T. Commercial-scale trials on the application of ethyl formate, carbonyl sulfide and carbon disulfide to wheat. In CSIRO Entomology Technical Report No. 75; CSIRO Division of Entomology: Canberra, Australia, 1998; p. 63.

16. Weller, G.L.; Morton, R. Fumigation with carbonyl sulfide: A model for the interaction of concentration, time and temperature. J. Stored Prod. Res. 2001, 37, 383-398. [CrossRef]

17. Weller, G.L. The role of concentration, time and temperature in determining dosage for fumigation with carbonyl sulfide. In Proceedings of the Seventh International Working Conference on Stored Product Protection, Beijing, China, 14-19 October 1998; Jin, Z., Liang, Q., Liang, Y., Tan, X., Guan, L., Eds.; Sichuan Publishing House of Science and Technology: Chengdu, China, 1999; pp. 548-553. 
18. Bartholomaeus, A.R.; Haritos, V.S. Review of the toxicology of carbonyl sulfide, a new grain fumigant. Food Chem. Toxicol. 2005, 43, 1687-1701. [CrossRef]

19. Daglish, G.J.; Nayak, M.K.; Pavic, H.; Smith, L.W. Prevalence and potential fitness cost of weak phosphine resistance in Tribolium castaneum (Herbst) in eastern Australia. J. Stored Prod. Res. 2015, 61, 54-58. [CrossRef]

20. Mutters, R.G.; Thompson, J.F. Rice Quality Handbook; UC ANR Publication: Oakland, CA, USA, 2009 ; p. 141.

21. Bell, C.H. Fumigation in the 21st century. Crop Prot. 2000, 19, 563-569. [CrossRef]

22. Fedina, T.Y.; Lewis, S.M. Effect of Tribolium castaneum (Coleoptera: Tenebrionidae) nutritional environment, sex, and mating status on response to commercial pheromone traps. J. Econ. Entomol. 2007, 100, 1924-1927. [CrossRef]

23. Mathlein, R. Rearing experiments with Oryzaephilus surinamensis L. and Cryptolestes ferrugineus Steph. on grain. Natl. Swed. Inst. Plant Prot. Contrib. 1971, 15, 187-203.

24. Champ, B.R.; Dyte, C.E. Report of the FAO global survey of pesticide susceptibility of stored grain pests. In FAO Plant Production and Protection Series Vol. 5; FAO: Rome, Italy, 1976.

25. AFHB/ACIAR Suggested recommendations for the fumigation of grain in ASEAN region. In Principles and General Practice, Part 1; ASEAN Food Handling Bureau: Kuala Lumpur, Malaysia, 1989; p. 139.

26. Khattak, S.U.; Khatoon, R.; Wahid, M. Insect attack and nutritional losses in stored dried fruits. Nucleus (Islamabad) 1999, 36, 113-116.

27. Matthews, G.A. Insecticide application in stores. In Application Technology for Crop Protection; Matthews, G.A., Hislop, E.C., Eds.; CABI international: Wallingford, UK, 1993; pp. 305-315.

28. Benhalima, H.; Chaudry, M.Q.; Mills, K.A.; Price, N.R. Phosphine resistance in stored-product insects collected from various grain storage facilities in Morocco. J. Stored Prod. Res. 2004, 40, 241-249. [CrossRef]

29. Kaur, R.; Nayak, M.K. Developing effective fumigation protocols to manage strongly phosphine-resistant Cryptolestes ferrugineus (Stephens) (Coleoptera: Laemophloeidae). Pest Manag. Sci. 2015, 71, 1297-1302. [CrossRef]

30. Koçak, E.; Schlipalius, D.; Kaur, R.; Tuck, A.; Ebert, P.; Collins, P.; Yilmaz, A. Determining phosphine resistance in rust red flour beetle, Tribolium castaneum (Herbst.)(Coleoptera: Tenebrionidae) populations from Turkey. Turk. J. Entomol. 2015, 39, 129-136. [CrossRef]

31. Nayak, M.K.; Jagadeesan, R.; Kaur, R.; Daglish, G.J.; Reid, R.; Pavic, H.; Collins, P.J. Use of sulfuryl fluoride in the management of strongly phosphine-resistant insect pest populations in bulk grain storages in Australia. Indian J. Entomol. 2016, 78, 100-107. [CrossRef]

32. Chen, Z.; Schlipalius, D.; Opit, G.; Subramanyam, B.; Phillips, T.W. Diagnostic molecular markers for phosphine resistance in US populations of Tribolium castaneum and Rhyzopertha dominica. PLoS ONE 2015, 10, e0121343.

33. Nayak, M.K.; Falk, M.G.; Enermy, R.N.; Collins, P.J.; Joanne, H.C. An analysis of trends, frequencies and factors influencing the development of resistance to phosphine in the red flour beetle Tribolium castaneum (Herbst) in Australia. J. Stored Prod. Res. 2017, 72, 35-48. [CrossRef]

34. Navarro, S.; Isikber, A.A.; Finkelman, S.; Rindner, M.; Azrieli, A.; Dias, R. Effectiveness of short exposures of propylene oxide alone and in combination with low pressure or carbon dioxide against Tribolium castaneum (Herbst) (Coleoptera:Tenebrionidae). J. Stored Prod. Res. 2004, 40, 197-205. [CrossRef]

35. KOTRA. Overseas Market News; Australian Wheat Imports, Need to Understand Local Logistics System and Price Structure to Secure Stable Raw Materials (Korean). Available online: http://news.kotra.or.kr/user/ globalBbs/kotranews/782/globalBbsDataView.do?setIdx=243\&dataIdx=125127 (accessed on 10 October 2020).

36. Kyung, Y.J.; Kim, H.K.; Lee, J.S.; Kim, B.S.; Yang, J.O.; Lee, B.H.; Koo, H.N.; Kim, G.H. Efficacy and phytotoxicity of phosphine as fumigants for Frankliniella occidentalis (Thysanoptera: Thripidae) on asparagus. J. Econ. Entomol. 2018, 111, 2644-2651. [CrossRef]

37. SAS Institute. SAS User's Guide, Statistics Version 9, 1st ed.; SAS Institute: Cary, NC, USA, 2009.

38. Pimentel, M.A.G.; Faroni, L.R.D.A.; Totola, M.R.; Guedes, R.N.C. Phosphine resistance, respiration rate and fitness consequences in stored-product insects. Pest Manag. Sci. 2007, 63, 876-881. [CrossRef]

39. Kaur, R.; Subbarayalu, M.; Jagadeesan, R.; Daglish, G.J.; Nayak, M.K.; Naik, H.R.; Schlipalius, D.I. Phosphine resistance in India is characterised by a dihydrolipoamide dehydrogenase variant that is otherwise unobserved in eukaryotes. Heredity 2015, 115, 188-194. [CrossRef]

40. Nayak, M.K.; Daglish, G.J.; Phillips, T.W.; Ebert, P.R. Resistance to the fumigant phosphine and its management in insect pests of stored products: A global perspective. Annu. Rev. Entomol. 2020, 65, 333-350. [CrossRef] 
41. Ducom, P.J.F. The return of the fumigants. In Proceedings of the Ninth International Working Conference on Stored Product Protection, Campinas, Brazil, 15-18 October 2006; Lorini, I., Bacaltchuk, B., Beckel, H., Deckers, D., Sundfeld, E., dos Santos, J.P., Biagi, J.D., Celaro, J.C., Faroni, L.R.D.A., Bortolini, L., et al., Eds.; Brazilian Post-harvest Association: Campinas, Brazil, 2006; pp. 510-516.

42. Xianchang, T.; Xingwei, H.; Lizheng, C.; Jianchun, W. Research on carbonyl sulfide as a fumigant for control of stored grain insects. In Proceedings of the Seventh International Working Conference on Stored Product Protection, Beijing, China, 14-19 October 1998; Jin, Z., Liang, Q., Liang, Y., Tan, X., Guan, L., Eds.; Sichuan Publishing House of Science and Technology: Chengdu, China, 1999; pp. 567-571.

43. Chaudhry, M.Q. Review A review of the mechanisms involved in the action of phosphine as an insecticide and phosphine resistance in stored-product insects. Pestic. Sci. 1997, 49, 213-228. [CrossRef]

44. Hsu, C.H.; Quistad, G.B.; Casida, J.E. Phosphine-induced oxidative stress in Hepa 1c1c7 cells. Toxicol. Sci. 1998, 46, 204-210. [CrossRef]

45. Haritos, V. Metabolism of carbonyl sulfide to hydrogen sulfide in insects is catalysed by carbonic anhydrase. In Proceedings of the International Conference on Controlled Atmospheres and Fumigation in Stored Products, Fresno, CA, USA, 29 October 2000; Executive Printing Services: Clovis, CA, USA, 2001; pp. 79-89.

46. Liu, B.; Zhang, F.; Wang, Y. Toxicity of phosphine to Carposina niponensis (Lepidoptera: Carposinadae) at low temperature. J. Econ. Entomol. 2010, 103, 1988-1993.

47. Llàcer, E.; Miret, J.A.J. Efficacy of phosphine as a fumigant against Rhynchophorus ferrugineus (Coleoptera: Curculionidae) in palms. Span. J. Agric. Res. 2010, 8, 775-779. [CrossRef]

48. Kim, H.K.; Lee, S.W.; Kim, J.I.; Yang, J.O.; Koo, H.N.; Kim, G.H. Synergistic effects of oxygen on phosphine and ethyl formate for the control of Phthorimaea operculella (Lepidoptera: Gelechiidae). J. Econ. Entomol. 2015, 108, 2572-2580. [CrossRef]

Publisher's Note: MDPI stays neutral with regard to jurisdictional claims in published maps and institutional affiliations. 